\title{
Privatization, Drought, and Fire Exclusion in the Tuul River Watershed, Mongolia
}

\author{
Thomas Saladyga, ${ }^{1 *}$ Amy Hessl, ${ }^{2}$ Baatarbileg Nachin,${ }^{3}$ and Neil Pederson ${ }^{4}$
}

\begin{abstract}
${ }^{1}$ Department of Geography, Concord University, P.O. Box 1000, Athens, West Virginia 24712-1000, USA; ${ }^{2}$ Department of Geology and Geography, West Virginia University, P.O. Box 6300, Morgantown, West Virginia 26506-6300, USA; ${ }^{3}$ Department of Forest Sciences, National University of Mongolia, Ulaanbaatar, Mongolia; ${ }^{4}$ Lamont-Doherty Earth Observatory, Columbia University, P.O. Box 1000,
\end{abstract} Palisades, New York 10964-8000, USA

\begin{abstract}
Global wildfire frequency and extent are expected to increase under projected climate change in the twenty-first century, yet little is known about how human activities might affect this trend. In central Mongolia, there has been a $2.5^{\circ} \mathrm{C}$ rise in spring and summer temperatures during the last 40 years and a decrease in moisture availability during the latter half of the twentieth century. Concurrently, Mongolia has experienced multiple shifts in socioeconomic systems during the twentieth century, most notably the establishment of a Soviet-backed communist economy in the 1920s and a rapid transition to privatization in the 1990s. Observed records of fire in the late twentieth century suggested that fire activity had increased, but no longterm data existed to place these trends in a historical context. Our objective was to identify spatial and temporal patterns in fire occurrence in the
\end{abstract}

forest-steppe ecotone of the Tuul River watershed in the context of changing climatic and social conditions since 1875 . We used fire-scarred trees to reconstruct past fire occurrence during the period 1875-2009. Our results indicate a significant association between human activity and fire occurrence independent of climatic variables. The greatest evidence for an anthropogenic fire regime exists following the transition to a free market economy during the early 1990s when land-use intensification near the capital city of Ulaanbaatar resulted in fire exclusion. We emphasize the importance of including socio-political variables in global models of wildfire potential, particularly where fuels limit fire activity.

Key words: Mongolia; wildfire; drought; dendrochronology; land use; privatization.
Received 30 November 2012; accepted 25 March 2013

Electronic supplementary material: The online version of this article (doi:10.1007/s10021-013-9673-0) contains supplementary material, which is available to authorized users.

Author Contributions: Thomas Saladyga was responsible for the conception and design of the study. Saladyga also performed background research, analyzed data, developed tables and figures, and wrote the paper. As the first author's Ph.D. advisor, Amy Hessl provided guidance in the conception and design of the study. Hessl also contributed to writing and editing the manuscript. Baatarbileg Nachin participated in the design of the study and provided comments throughout the writing process. Neil Pederson contributed to research and participated in editing the manuscript.

*Corresponding author; e-mail: saladygat@concord.edu

\section{INTRODUCTION}

Sustainable use and management of forest resources will be integral to preventing landscape degradation as rapid changes in climate (for example, temperature and precipitation) are expected to alter historic fire regimes during the coming century (Overpeck and others 1990; Dale and others 2000; Sivakumar and others 2005). This is especially critical in regions of the world where lands with low productivity are vulnerable to abrupt changes in climate and land-use pressure. 
The earliest and most extreme increases in temperature are expected to occur at high latitudes, whereas many arid and semi-arid regions will experience increased drought incidence (IPCC 2007). Changes in hydroclimatic regimes are expected to have profound effects on fire occurrence such as increased fire frequency and a longer fire season (Wotton and Flannigan 1993; Stocks and others 1998; McKenzie and others 2004; Westerling and others 2006; Kilpeläinen and others 2010; Yang and others 2011). Despite increasing temperatures, however, fire activity in northern forests might not be as severe as globally predicted (Flannigan and others 1998) and changes in ignition sources and forest fuels might limit future fire regimes, particularly in semi-arid systems (Hessl 2011). Changes in hydroclimatic conditions and fire occurrence will have substantial influence on the livelihoods of those dependent upon local environments and may have important implications for feedbacks to the atmosphere stemming from altered rates of carbon sequestration and evapotranspiration (Field and others 2007; Chapin and others 2008b).

Pastoralist societies in central Asia have a long history of sustainable range and forest management across the expansive steppe and forest-steppe ecosystems of the region. In Mongolia, herders have historically managed livestock in a manner that makes efficient use of spatially and temporally heterogeneous resources (Fernández-Giménez 1999). However, shifts in social and economic conditions, most notably during the twentieth century, have impacted pastoralist mobility, access to resources, and land tenure (Fernández-Giménez 2006; Johnson and others 2006). The region has experienced warming temperatures (Jacoby and others 1996; D'Arrigo and others 2000, 2001) and a sudden decrease in moisture availability in the 1990s ( $\mathrm{Li}$ and others 2008), which followed three strong pluvials during the twentieth century (Davi and others 2013; Pederson and others 2013). Consistent with these findings, Mongolia has experienced a recent increase in frequency and intensity of droughts, with a drought from 1999 to 2002 affecting approximately 70\% of the country's grasslands and killing about 12 million livestock (Batima and others 2005). Drought in 2009, followed by a harsh winter in 2010, resulted in the death of more than 7.8 million livestock (FAO United Nations 2010).

Climate change in the twentieth and twenty-first centuries in Mongolia has occurred alongside major social and economic transitions that have directly affected land use. The history of changes in land- use patterns, land-use regulation, and land tenure in Mongolia during this period can be divided into four eras: Manchu rule and autonomy (pre-1911); early communism (1924-1959); collective (19601990); and privatization (1992-present) (Fernández-Giménez 1999). During Manchu rule and autonomy, pastoralist movements were frequent, covered long distances and utilized multiple ecological zones. This mobility decreased during the early communism era when some lands experienced year-round grazing. Although some herders maintained seasonal rotation of pasture during the collective era (1960-1990), their mobility was reduced even further, limiting access to the full variety of ecological zones and forage resources used traditionally. The transition from a centrally planned economy to a market economy, including the privatization of livestock (early 1990s), marked a further decrease in pastoral mobility, as seen in an increase in the number of inexperienced herders, increased trespassing on leased pastureland, a concentration of livestock near towns and roads, and reduced frequency and distance of moves (Fernández-Giménez 2006). Mongolia's livestock population remained relatively stable during the communist era, but increased sharply (especially goats for Kashmir textiles) after privatization in the 1990s and has experienced multiple crashes during the twenty-first century (Sankey and others 2006). Despite these crashes, decreased pastoralist mobility and a general trend of increasing livestock numbers in the late twentieth and twenty-first centuries led to a spatially heterogeneous landscape of fine fuels due to overgrazing in some areas (Sneath 1998).

Where human land use and increasing aridity combine to reduce fuel volume, forests might not experience increases in fire occurrence that are expected under projected climate change (Honig and Fulé 2012). Reduced moisture availability, rising temperatures, and intensifying land-use pressure are known to contribute to changes in fire frequency and extent at least in some regions (Donnegan and others 2001; Grissino-Mayer and others 2004; Westerling and others 2006). Grazing in particular has had strong impacts on forest age structure, fine fuel volume and continuity, and fire regimes in other semi-arid regions (Savage and Swetnam 1990; Grissino-Mayer and others 1995; Swetnam and Betancourt 1998). Similar controls may act on wildfires in Mongolia's forest-steppe ecotone. The observed frequency and aerial extent of forest and grassland fires in Mongolia markedly increased during the period 1963-1997 (Goldammer 2002) coincident with both rising temperatures and 
changes in land use. The purpose of this study was to assess human and climatic influences on fire occurrence during the period 1875-2009 in the Upper Tuul River watershed (UTRW) in central Mongolia. We expect that an intensification of human activities (that is, grazing and logging) following the transition to a market economy in the early 1990s marked a significant change in fire occurrence and location. Specifically, we hypothesize that (1) forest fuels are reduced by human presence via grazing, logging, and fuelwood collection and (2) novel fire regimes have resulted, independent of climatic influence, from changes in land-use patterns, land-use regulation, and land tenure, most notably following the shift to a market economy in the early 1990s.

\section{METHODS}

\section{Study Area}

The Tuul River watershed makes up only $3.2 \%$ of the total land area of Mongolia (Figure 1), but is home to more than half of the country's population, most of which is located in the capital city of Ulaanbaatar (pop. 1,221,000 in 2012). Ulaanbaatar has been the center of economic and political activities since its permanent settlement in 1778 .

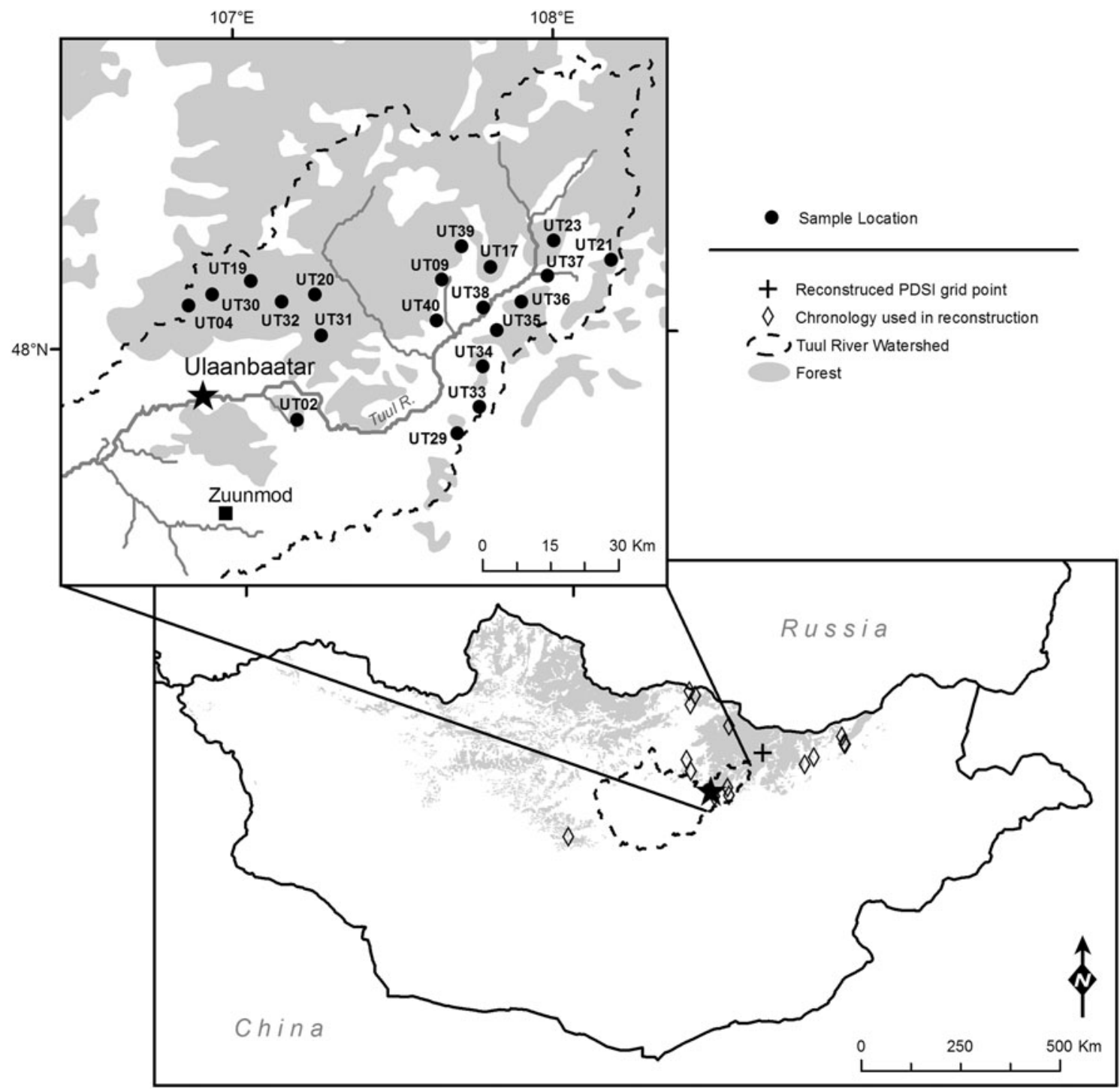

Figure 1. Map of Mongolia showing the location of the reconstructed PDSI grid point (plus sign) (Dai and others 2004) and the tree-ring chronologies used in the April-August PDSI reconstruction (open diamonds). Map inset Sample locations (solid circles) in the Upper Tuul River watershed (dashed line). 
Population in the industrial capital increased significantly following Mongolia's transition to a privatized economy in the early 1990s, but has doubled between 2009 and 2012. The UTRW includes the upper reaches of the Tuul River and its tributaries, including a drainage area of $8,735 \mathrm{~km}^{2}$ and a boundary that extends approximately $180 \mathrm{~km}$ from southwest of Bogd Khan Uul (mountain) to the northeast into the higher elevation Khan Khentii Mountains (Figure 1 inset). Land and resources of the UTRW currently contribute income and marketed products worth around Tug 28 billion ( $\sim 22$ million USD) per year in tourism, herding, and forest-based sectors (Emerton and others 2009). Therefore, in representing the most extreme range of urban to rural development in Mongolia, the UTRW is an ideal case study for exploring human impacts on wildfire in semi-arid Asia.

Mongolia is characterized by an extreme continental climate. Average temperatures in central Mongolia range from approximately $-18^{\circ} \mathrm{C}$ in winter to approximately $16^{\circ} \mathrm{C}$ in summer, though winter temperatures have been rising since the 1940s (Davagdorj and Mijidorg 1996; Jacoby and others 1996). Total annual precipitation is low (252 mm) and peaks in summer when approximately $72 \%$ of precipitation falls (Davagdorj and Mijidorg 1996). Between 1940 and 2001, spring precipitation declined $17 \%$ (Batima and others 2005). No single synoptic system appears to strongly influence Mongolian climate except perhaps the winter Siberian High, centered over Mongolia from winter through late spring (Samel and others 1999; D'Arrigo and others 2005) and interactions between El Niño and Indian Ocean Dipole Events (Ummenhofer and others 2013).

Forested area in the UTRW totals $3,876 \mathrm{~km}^{2}$ with $55 \%$ dominated by Larix sibirica, $42 \%$ by Pinus spp., and the remaining 3\% by Betula spp., Abies sibirica, and Picea obovata (Ministry of Nature and Environment 2009). Elevation in the UTRW ranges from $1,187 \mathrm{~m}$ just southwest of Ulaanbaatar to $2,795 \mathrm{~m}$ (Asralt Khairkhan Uul) in the Khentii Mountains. The mountains are situated at the interface between the western Siberian dark taiga (Picea obovata, A. sibirica, Pinus sibirica, and L. sibirica), the eastern Siberian light taiga (Betula platyphylla, L. sibirica, and Pinus sylvestris), and the Mongolian forest-steppe zone (Ermakov and others 2002). This region is particularly species rich, relative to the rest of central Asia, due to the intersection of boreal, temperate, and steppe vegetation. Three conservation areas exist with the Khentii region including the Strictly Protected Area of Khan Khentii (12,300 km²; est. 1992), Gorkhi-Terelj
National Park $\left(2,900 \mathrm{~km}^{2}\right.$; est. 1993), and OnonBalj National Park $\left(4,200 \mathrm{~km}^{2}\right.$; est. 2000). The two National Parks have been developed for tourism, but within the Khan Khentii Strictly Protected Area, tourism is tightly managed and hunting and mining are prohibited. However, use of resources by local residents, including grazing, fuelwood collection, and logging is difficult to manage in all conservation areas due to a lack of funding.

Based on data for the period 1963-1997, the fire season in Mongolia has two peaks with $80 \%$ of fires occurring between March and mid-June, and $5-8 \%$ occurring during a short period in September and October (Valendik and others 1998). Fires are rare during the summer months when precipitation is greatest. Annually, 50-60 forest fires occur in Mongolia, of which $95 \%$ are thought to be human caused (Goldammer and others 2004). Unlike other pastoralists, Mongolian herders are not known to deliberately use fire to clear land or encourage grassland productivity (personal communication with forestry officer), suggesting that the majority of these ignitions are unintentional.

\section{Sample Design}

To evaluate spatial and temporal changes in fire occurrence and land use, we randomly located 20 , 4 ha $(200 \mathrm{~m} \times 200 \mathrm{~m})$ sample sites within the forest-steppe ecotone of the UTRW in July/August 2010. We developed a GIS-based index of human impact to stratify our samples across a land-use intensity gradient (Saladyga 2011). The index was based on distance to the nearest urban center and urban population, distance to the nearest road and road type (paved/dirt track), and elevation. We used this index to locate sample locations along a gradient of potential human disturbance. All sites fall into the very high, high, or medium classes of natural fire danger established by Arkhipov and others (2000) and are composed of pure stands of L. sibirica or mixed Larix/Pinus stands dominated by L. sibirica. Our sample design targeted an elevation range of 1,500-2,000 $\mathrm{m}$ and includes an area of $2,620 \mathrm{~km}^{2}$ (of a total forested area of $3,876 \mathrm{~km}^{2}$ within the UTRW).

\section{Qualitative Site Assessment}

We used a rapid (15 min per site), qualitative onsite assessment to identify the magnitude of present-day human impacts at each site. We looked for evidence of fire, grazing, and logging, and scored each variable $(0-3)$ based on the presence and area of impacts (ocular estimations). Evidence of fire included charcoal on soil, charred woody debris, cat 
faces (cambial damage), scorch height, and heatkilled snags $(\max$ score $=15)$. Grazing indicators included the presence of dung, hoof prints, livestock remains and trails $(\max$ score $=12)$. Indicators of logging disturbance included the presence of stumps, slash, machinery tracks, and other altered microtopography $(\max$ score $=12)$.

\section{Fuel Inventory}

Four, 15-m long planar transects were established at random bearings within each 4 ha site to assess fuel loads since last fire in the UTRW. Litter depths, fine woody debris (FWD, $<7.62 \mathrm{~cm}$ diameter), and coarse woody debris (CWD, $>7.62 \mathrm{~cm}$ ) were measured following methods described by Brown (1974) and Passovoy and Fule (2006). FWD was inventoried in three size classes (0-0.64, 0.65-2.54, and $2.55-7.62 \mathrm{~cm}$ ), which correspond to 1-, 10-, and 100-h moisture time-lag classes, whereas CWD (down wood $>7.62 \mathrm{~cm}$ diameter) corresponds to the 1000-h moisture time-lag class (Brown 1974).

\section{Fire Chronology}

We sampled all fire-scarred trees (stumps, snags, and living trees) within the 4 ha search area, collecting on average seven samples per site $(\min =1$, $\max =13$ ), depending on site history. Sites with a frequent history of burning typically had ample fire scar evidence; however, several sites had little to no evidence of recent fire. Fire-scarred trees were sampled by identifying trees with evidence of cambial damage (that is, "cat face"), from which partial cross sections were removed with a chainsaw (Arno and Sneck 1977). We surfaced all firescar samples with progressively finer grit sandpaper until cells were clearly visible under magnification according to established tree-ring procedures (for example, Stokes and Smiley 1968). We then crossdated samples using an already established tree-ring chronology (Jacoby and others 2009, International Tree-Ring Data Bank, Manzhir Hiid) to provide absolute dates for all tree rings and fire scar injuries. If possible, we assigned the season of occurrence to each fire scar based on its position within a ring (Baisan and Swetnam 1990). Because $80 \%$ of all fires in the modern record occur from March to mid-June, we assumed that fires with unknown season most likely occurred during this period (Nyamjav and others 2007). Consequently, we assigned fire scars that fell within the dormant season to the subsequent year. Site-level fire histories were compiled into a watershed composite of the percentage of sites recording fire (for example, Guyette and others 2002; Brown and others 2008). We used unfiltered fire scar data to maximize sample size for all analyses except fire-climate relationships, for which a two-scar per site filter was applied.

\section{Correlation and Cluster Analysis}

Pearson correlation coefficients were calculated to assess basic relationships between qualitative disturbance evidence, years since last fire, and fuels data. To further understand drivers of recent fire activity, we used principal components analysis (PCA) to convert these variables into component scores. Principal components (PCs) with eigenvalues greater than 1.0 were extracted to explain model variance and an agglomeration schedule was used to pre-select the appropriate number of clusters for further analysis. We then used these PCA scores in $k$-means cluster analysis, which partitions observations into groups based on Euclidean distance from mean cluster centers, to identify clusters of sites characterized by similar disturbance, fuels, and fire activity.

\section{Political/Economic Eras and Fire Activity}

We used the non-parametric Kruskal-Wallis test to assess differences between political/economic eras in the percentage of sites recording fire. The percentage of fire years for each site was calculated for each political/economic era and tested for spatial autocorrelation (Moran's I) to examine changes in the spatial distribution of fire occurrence. Political/ economic eras were modified slightly from Fernández-Giménez (1999). These classifications include (1) Manchu rule and autonomy, including Chinese occupation and independence, 18751923; (2) early communism, 1924-1959; (3) collective, 1960-1990; and (4) privatization, 19912009.

\section{Climate-Fire Relationships}

We used superposed epoch analysis (SEA) (for example, Grissino-Mayer and Swetnam 2000; Taylor and Beaty 2005) to test our hypothesis about the overriding impacts of land use on fire occurrence. We expected that drought would not be associated with fire activity, particularly when and where human impacts were strong. To compare fire events with climate, we developed an independent tree-ring reconstruction of April-August 
Table 1. Sample Locations in the UTRW Including $k$-Means Clusters, Latitude, Longitude, Elevation (m), Number of Samples, Total Number of Dated Scars and Injuries, and First and Last Ring Dates

\begin{tabular}{|c|c|c|c|c|c|c|c|c|c|}
\hline Site ID & $\begin{array}{l}\text { K-means } \\
\text { cluster }\end{array}$ & Lat. & Long. & Elevation (m) & No. samples & No. scars & No. injuries & First ring & Last ring \\
\hline UT02 & 1 & 47.842 & 107.171 & 1,734 & 1 & 9 & 0 & 1833 & 2001 \\
\hline UT04 & 1 & 48.085 & 106.846 & 1,725 & 5 & 9 & 0 & 1857 & 2009 \\
\hline UT09 & 3 & 48.123 & 107.629 & 1,620 & 9 & 50 & 16 & 1753 & 2009 \\
\hline UT17 & 3 & 48.146 & 107.782 & 1,683 & 7 & 26 & 8 & 1626 & 2009 \\
\hline UT19 & 3 & 48.133 & 107.039 & 1,707 & 1 & 1 & 0 & 1962 & 2009 \\
\hline UT20 & 2 & 48.101 & 107.236 & 1,755 & 8 & 13 & 1 & 1868 & 2009 \\
\hline UT2 1 & 3 & 48.152 & 108.155 & 1,793 & 11 & 25 & 0 & 1782 & 2009 \\
\hline UT23 & 3 & 48.196 & 107.981 & 1,788 & 10 & 20 & 3 & 1869 & 2009 \\
\hline UT29 & 3 & 47.804 & 107.661 & 1,991 & 4 & 16 & 7 & 1488 & 2009 \\
\hline UT30 & 1 & 48.106 & 106.920 & 1,712 & 5 & 6 & 0 & 1889 & 2009 \\
\hline UT31 & 1 & 48.016 & 107.252 & 1,688 & 8 & 9 & 3 & 1864 & 2007 \\
\hline UT32 & 2 & 48.088 & 107.134 & 1,640 & 6 & 8 & 3 & 1865 & 2009 \\
\hline UT33 & 3 & 47.858 & 107.733 & 1,676 & 10 & 16 & 6 & 1945 & 2009 \\
\hline UT34 & $\mathrm{n} / \mathrm{a}$ & 47.941 & 107.747 & 1,834 & 0 & $\mathrm{n} / \mathrm{a}$ & $\mathrm{n} / \mathrm{a}$ & $\mathrm{n} / \mathrm{a}$ & $\mathrm{n} / \mathrm{a}$ \\
\hline UT35 & 3 & 48.015 & 107.794 & 1,699 & 13 & 33 & 19 & 1808 & 2009 \\
\hline UT36 & 2 & 48.072 & 107.874 & 1,648 & 10 & 28 & 3 & 1869 & 2009 \\
\hline UT37 & 3 & 48.124 & 107.958 & 1,629 & 12 & 22 & 7 & 1942 & 2009 \\
\hline UT38 & 1 & 48.063 & 107.756 & 1,571 & 7 & 17 & 15 & 1626 & 2009 \\
\hline UT39 & 2 & 48.191 & 107.695 & 1,676 & 8 & 19 & 11 & 1755 & 2009 \\
\hline UT40 & 2 & 48.039 & 107.610 & 1,666 & 5 & 26 & 2 & 1625 & 2009 \\
\hline
\end{tabular}

PDSI (Palmer Drought Severity Index) near the study area using existing tree-ring chronologies and instrumental data from Dai and others (2004) (grid point $48.75 \mathrm{~N}, 108.75^{\circ} \mathrm{E}$; Figure 1). Fifteen tree-ring chronologies (see Appendix 1 in Supplementary material) and 20 of the 30 possible predictors from all chronologies $(t$ and $t+1)$ were significantly correlated $(\alpha=0.05)$ with AprilAugust PDSI during the common period (18151994). We used PCA and forward and backward nesting procedures to extend the reconstruction from the year 1675 to 2000 (Meko 1997; Cook and others 2002; Saladyga 2011). The final reconstruction accounts for $60 \%$ of the variance in average April-August instrumental PDSI for the period 1945-1993.

We used SEA to compare our reconstructed average annual April-August PDSI values to our site and watershed-level fire chronologies for the six preceding and 4 years following an event. We applied a two-scar per site filter to eliminate local, spot fires in our fire chronology. SEA uses Monte Carlo simulations (1,000 runs) to compare average climatic conditions prior to, during, and following event years to conditions present over the entire fire chronology. Significant departures in PDSI were identified as those exceeding the 95\% confidence interval (Grissino-Mayer 2001).

\section{RESULTS \\ Fire History}

Fire history analyses were limited to the period 1875-2009 due to a substantial decrease in sample size prior to the late nineteenth century. We reconstructed past surface fire timing from all firescarred trees sampled ( $n=140)$ (Table 1; Figure 2). We identified and dated a total of 353 fire scars ( $52 \%$ dormant season, $18 \%$ early wood, $2 \%$ middle wood, and $28 \%$ unknown) and 104 cambial injuries for 19 of the 20 sites. No evidence of fire was observed at site UT34, which eliminated this site from further analysis. Sites with only a few firescarred trees have either burned at a temperature too low to scar a tree during the last approximately 150 years (given typical sample preservation) or have experienced stand-replacing fires, though we observed no evidence (for example, even-aged recruitment, charred standing snags) to support the latter. Fire scar samples recorded a total of 85 sitelevel and 15 watershed-level $(\geq 20 \%$ sites recording) fire events from 1877 to 2009. The most extensive event occurred in 1914, when $56 \%$ of sites recorded fire. Forty-one local fire events $(\leq 10 \%$ sites recording) were recorded. The most recent major fire events in the study area occurred in 1996 and 1997 when much of 


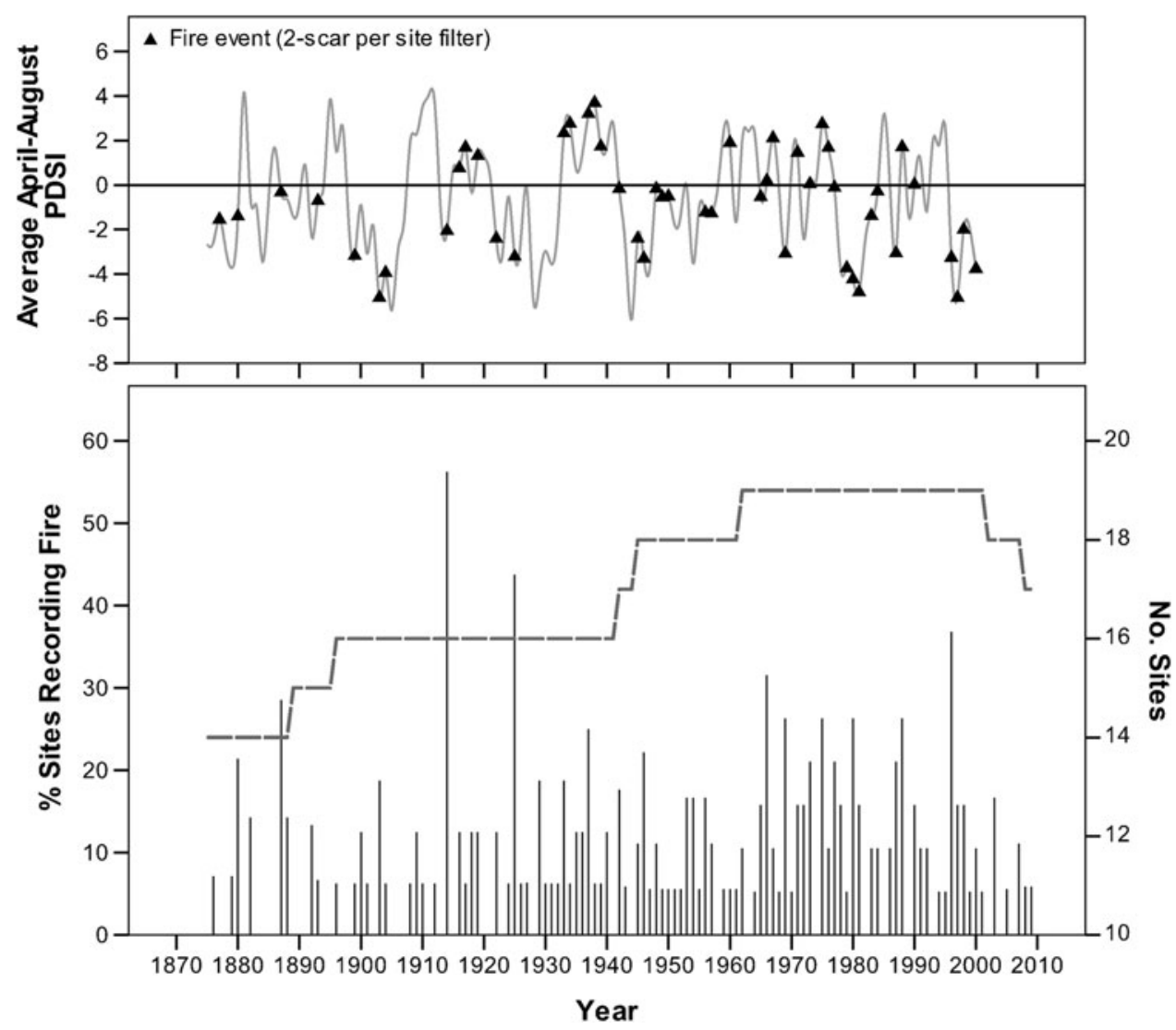

Figure 2. Above Reconstructed AprilAugust PDSI with fire events (solid triangles) using a 2-scar per site filter. There is a documented fire event in 2009 at UT19, but no corresponding PDSI data exist. Below Percentage of sites recording fire (bars) and number of sites (dashed line).

Table 2. Pearson Correlation Coefficients $(r)$ for Qualitative Disturbance Evidence and Quantitative Data (Years Since Last Fire and Fuel Volume)

\begin{tabular}{|c|c|c|c|c|c|c|c|c|}
\hline Qualitative evidence & Grazing & Logging & Fire & Years since last fire & Litter depth & l-h fuel & 10-h fuel & 100-h fuel \\
\hline Grazing & - & - & - & - & - & - & - & - \\
\hline Logging & $0.464^{*}$ & - & - & - & - & - & - & - \\
\hline Fire & -0.311 & -0.206 & - & - & - & - & - & - \\
\hline \multicolumn{9}{|l|}{ Quantitative data } \\
\hline Years since last fire & 0.257 & $0.602 * *$ & $-0.720 * *$ & - & - & - & - & - \\
\hline Litter depth & -0.058 & -0.353 & -0.273 & -0.123 & - & - & - & - \\
\hline 1-h fuel & 0.074 & -0.110 & -0.242 & -0.097 & $0.497^{*}$ & - & - & - \\
\hline 10-h fuel & 0.285 & 0.224 & $-0.646^{* *}$ & $0.480 *$ & 0.154 & 0.311 & - & - \\
\hline 100-h fuel & -0.510 * & -0.343 & $0.500^{*}$ & -0.296 & -0.134 & -0.262 & -0.332 & - \\
\hline
\end{tabular}

Mongolia experienced extensive wildfire (Goldammer 2002). In comparison to the 1914 event, the 1996 and 1997 fire events were recorded at only 37 and $16 \%$ of the sites, respectively.

\section{Disturbance, Fuels, and Recent Fire Activity}

Pearson correlation coefficients were calculated for qualitative disturbance variables, years since last fire, and forest fuels data (Table 2). Grazing and logging evidence are positively correlated $(r=0.464, P<0.05)$, whereas both are negatively related to fire evidence. A significant negative relationship exists between grazing evidence and 100-h fuels $(r=-0.510, P<0.05)$, likely resulting from fuelwood collection by herders. No other relationships were observed between disturbance and forest fuels. A significant positive relationship exists between logging evidence and years since last 
Table 3. K-Means Clusters and Median Values for Qualitative Disturbance Evidence, Years Since Last Fire, and Fuel Volume

\begin{tabular}{|c|c|c|c|c|c|c|c|c|}
\hline \multirow[t]{2}{*}{$K$-means cluster } & \multirow[t]{2}{*}{ Years since last fire } & \multicolumn{3}{|c|}{ Qualitative (\% max score) } & \multirow[t]{2}{*}{ Litter $(\mathrm{cm})$} & \multicolumn{3}{|c|}{ Fuels $\left(\mathrm{kg} / \mathrm{ha} \times 10^{2}\right)$} \\
\hline & & Grazing & Logging & Fire & & $1-h$ & $10-\mathrm{h}$ & $100-\mathrm{h}$ \\
\hline $1(n=5)$ & 21 & 33.3 & 50.0 & 20.0 & 1.63 & 0.61 & 0.79 & 0.26 \\
\hline $2(n=5)$ & 13 & 25.0 & 16.7 & 26.7 & 2.69 & 2.12 & 0.72 & 0.51 \\
\hline $3(n=9)$ & 13 & 16.7 & 16.7 & 60.0 & 1.94 & 0.61 & 0.39 & 1.05 \\
\hline
\end{tabular}

Qualitative disturbance evidence is expressed as the median percentage of maximum scores (grazing max score $=12$, logging max score $=12$, fire max score $=15$ ).

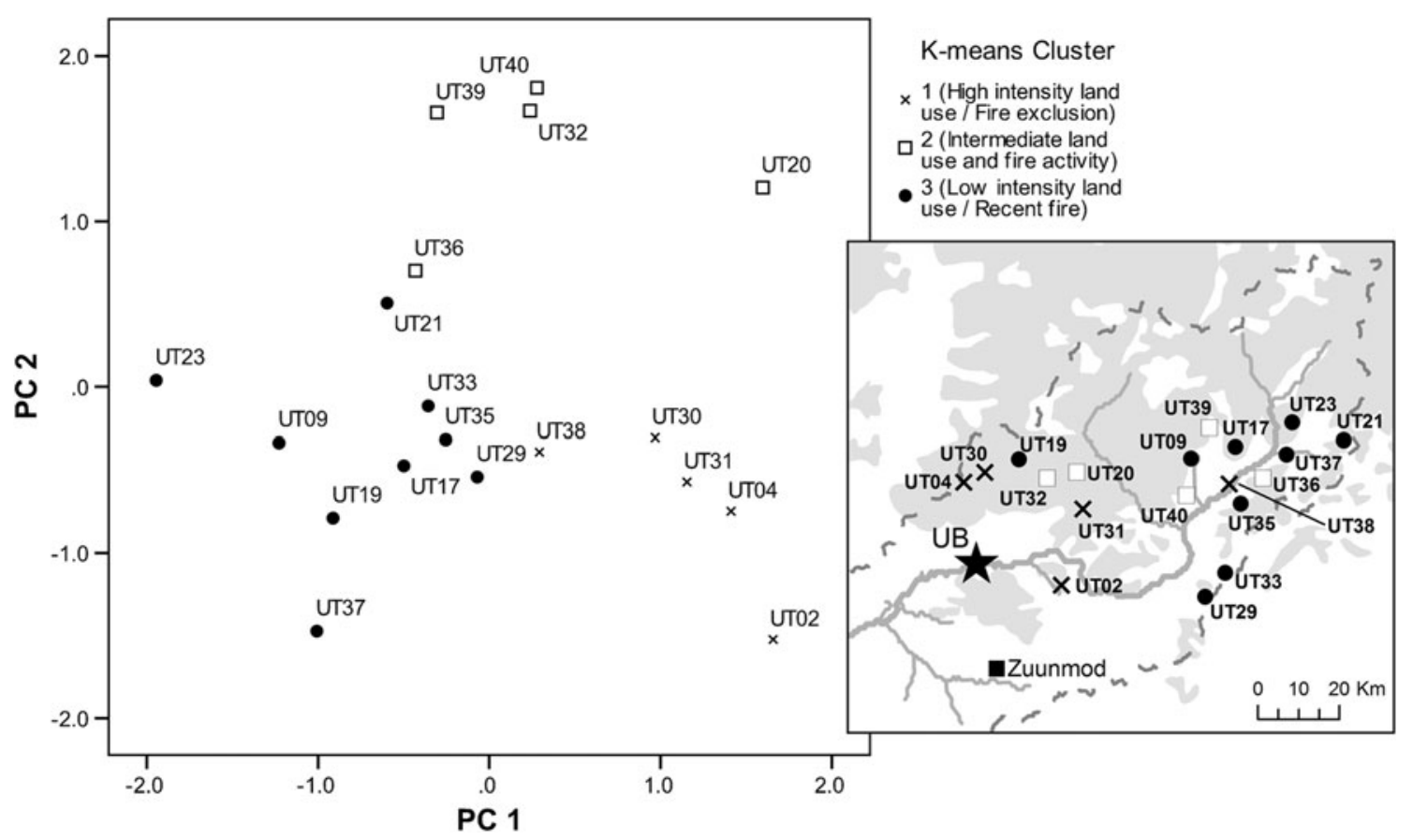

Figure 3. PC scores for qualitative disturbance evidence, years since last fire, and fuels data. $K$-means cluster analysis has grouped sites according to land-use intensity and fire activity (UT34 not included in analysis): high intensity land use/fire exclusion (" $x$ "); intermediate land use and fire activity (open squares); low intensity land use/recent fire (solid circles).

fire $(r=0.602, P<0.01)$. In total, these results suggest that human presence and land-use activities such as grazing and logging are associated with reduced fuels and reduced fire occurrence.

We used PCA and $k$-means cluster analysis to separate sites based on qualitative and quantitative variables. PC1 and PC2, with eigenvalues greater than 1.0 , explain $62 \%$ of the variance in the model. These PCs were used in $k$-means cluster analysis, which identified three clusters of sites $(P<0.001$; Table 3; Figure 3). Cluster 1 includes five sites (26\% of all sites; UT34 not included) that have experienced recent fire exclusion via intense landuse pressure. Four of these sites are located in the vicinity of Ulaanbaatar, whereas the fifth (UT38) is located along a travel corridor adjacent to the main branch of the Tuul River (Figure 3). Clusters 2 and
3 represent intermediate and low use sites with more frequent and/or more recent fire activity located further away from the center of human activities.

\section{Political/Economic Eras and Fire Activity}

The percentage of sites recording fire differs significantly between political/economic eras $(\mathrm{K}-\mathrm{W}=11.996, \quad P=0.007)$. Fire-free periods become less frequent during the twentieth century as a possible result of changing land-use patterns, regulation, and land tenure (Figure 2). Fires occurred in a statistically spatially random pattern (Moran's $I=0.06, P>0.05)$ during Manchu rule/autonomy and early communism, but tended to occur most frequently in one concentrated area 


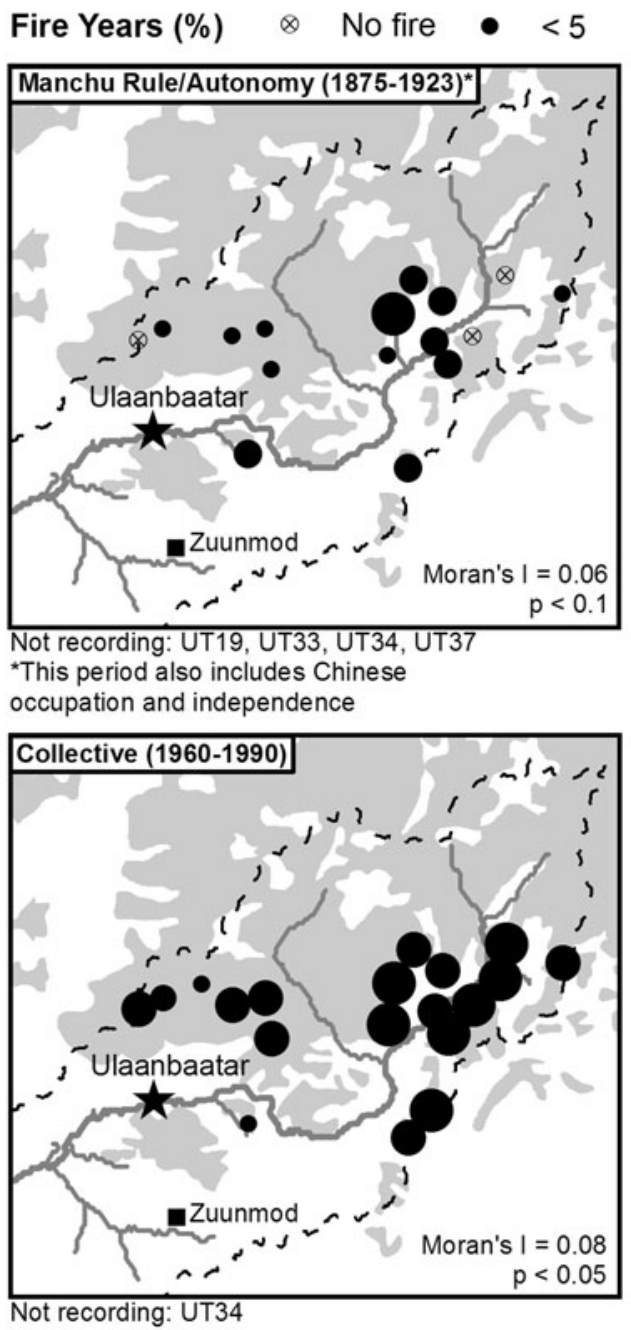

\section{5-15 > > $>15$}

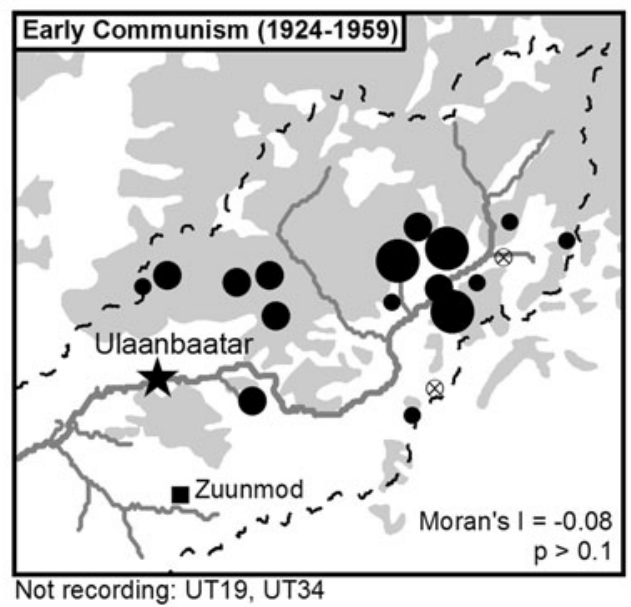

Not recording: UT19, UT34

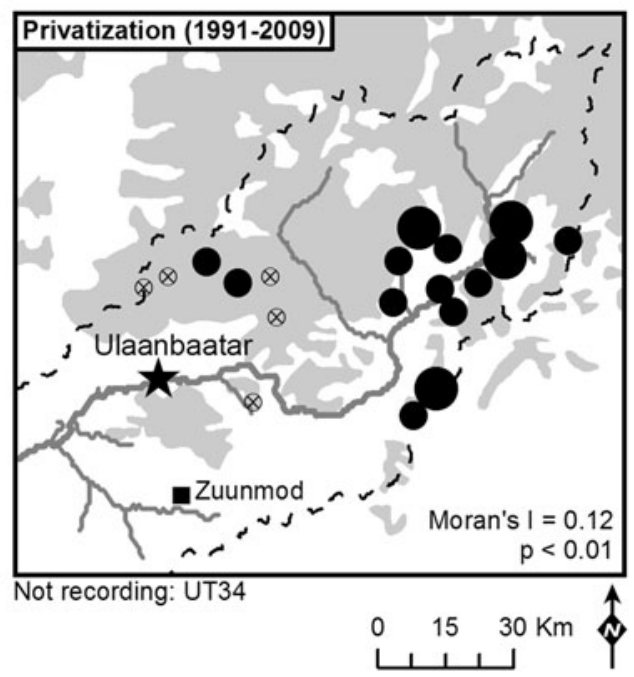

Figure 4. Maps of percent fire years (number of fire event years/total years recording) at each site for selected political/ economic eras, including Manchu rule and autonomy (1875-1923), early communism (19241959), collective (19601990), and privatization (1991-2009). Circle size denotes percent fire years, with larger circles indicating a higher percentage of years in which fire events were recorded and open circles with cross-hairs indicating that no fire event was observed in the tree-ring record. east of Ulaanbaatar (Figure 4). Fire occurrence was most frequent during the collective era, with most fire activities clustered in more remote areas to the east and northeast of Ulaanbaatar (Moran's $I=$ $0.08, P<0.05)$. This clustering pattern intensifies during privatization (Moran's $I=0.12, P<0.01$ ) as fire occurrence becomes increasingly unevenly distributed among study sites. Only two sites (UT19 and UT32) within $35 \mathrm{~km}$ of Ulaanbaatar recorded fire during this period.

\section{Fire-Climate Relationships}

During the early communism, collective, and privatization eras, fires occurred during both dry and wet years, but throughout Manchu rule and autonomy, fires occurred during dry years only (Figure 2). Over the entire study period, SEA indicates that climate was not unusually dry or wet in the years before, during, or following fire years (1875-2009), $(n=50)$. When we included only filtered watershed fire events ( $\geq 20 \%$ sites recording fire; $n=7$ ), we observed a significant departure 6 years prior to fire years, but this probably has little influence on the timing of these larger scale events. Average AprilAugust PDSI during watershed fire years was less than any year in the 11 -year analysis period, but not significantly so. These results indicate little or no relationship between drought and fire occurrence post Manchu rule, though the number of events tested for watershed fire events was low.

\section{Discussion}

Wildfire potential is expected to increase during the twenty-first century due to projected increases in temperature and extended fire seasons in many regions, including central Asia (for example, Spracklen and others 2009; Liu and others 2010). How human institutions, policies, and land uses 
might interact with changing climate to affect fire has received less attention. Our results indicate that changing social and economic policies in Mongolia during the twentieth century affected fuel volumes resulting in changes in fire activity in time and space. Our results further indicate that these landuse changes may have overwhelmed the effects of climate variability on fire typically observed in semi-arid forests in other regions of the world.

Contrary to model projections of fire based on climate change (Westerling and others 2006; Running 2006; Chapin and others 2008a; Fried and others 2008; Girardin and Mudelsee 2008; Kasischke and others 2010) and results from recent studies based on instrumental data (Goldammer and others 2004), fire occurrence in the Tuul River watershed of central Mongolia does not appear to be increasing, at least over the last 140 years (Figure 2). The most widespread events occurred in the early twentieth century (1914 and 1925) during drought years following multi-year pluvial events. Though fires during 1996 and 1997 were quite widespread, they do not appear to be beyond the range of variability of the recent past and cannot be directly attributed to warmer temperatures. Fire occurrence was most common and widespread during the collective era when climate conditions in Mongolia were unusually wet (Davi and others 2013; Pederson and others 2013), suggesting that changing socioeconomic conditions, rather than drought, may have played a role in the temporal pattern of fire occurrence we observed here.

Changing social conditions during the 1990s, including high rates of unemployment, forced many people in Mongolia to depend on forest resources (for example, fuelwood, logging, haymaking, and hunting) for livelihood and/or survival (United Nations Economic and Social Council 2002). During this period, nomads concentrated livestock near urban areas and further reduced the frequency and distance of their moves, locally reducing fine fuels (Fernández-Giménez 1999; Sankey and others 2006). Not only have these social and economic conditions affected fire occurrence through time, but they likely affected fire occurrence in space as well. As policies changed from collectivization to privatization, fire activity became increasingly unevenly distributed. Sites near Ulaanbaatar ( $k$-means cluster group 1) experienced near total fire exclusion whereas sites more distant to the city ( $k$-means cluster groups 2 and 3 ) experienced some limited fire activity in the last few decades. This modern pattern of fire activity is essentially the mirror image of the pattern during Manchu rule, when sites proximal to the city experienced more fire than those farthest away (Figure 4). Although less is known about land use in the Tuul River watershed during Manchu rule, we speculate that land-use management practices implemented by Monasteries (that is, frequent, long-distant pastoralist movements) resulted in infrequent, but spatially extensive fire years (Figure 2).

Fire activity in semi-arid coniferous forests in other regions of the world is tightly coupled with drought (Kitzberger and Veblen 1997; GrissinoMayer and Swetnam 2000; Hessl and others 2004; Trouet and others 2010). Here we observed no clear relationship between drought and fire either during the year of the fire or in the years leading up to the fire year, except for during Manchu rule when pastoralist land use may have been less intensive. As stated above, we also observe no clear positive trend in fire activity associated with the near $2.5^{\circ} \mathrm{C}$ warming that has occurred in Mongolia since the 1940s (Batima and others 2005). We propose that human modifications of fuel volume and continuity via grazing, logging, and fuelwood collection have overwhelmed the effect of climatic variability on fire occurrence in this semi-arid, highly impacted watershed. Human disturbances have influenced fire regimes in many parts of the world by altering forest structure and fuel volume (Veblen and others 1999; Guyette and others 2002; Hellberg and others 2003; Keeley and Lubin 2003). At nearby Bogd Mountain, fire events are absent in the tree-ring record beginning in the 1760 s following the permanent settlement of adjacent Ulaanbaatar and in the absence of any clear climatic changes (Hessl and others 2012). Similar patterns resulting from intensive grazing specifically have been observed in Spain (Rozas 2003), the Colorado Front Range (Mast and others 1998), and southeastern Arizona (Grissino-Mayer and others 1995). In central Mongolia, widespread fires might occur during the initial years of drought conditions (that is, 1914 and 1996/1997), but our results suggest that the spatial and temporal patterns of fire activity in areas with intensive grazing and logging may largely be a function of human land use.

Our results support the idea that socioeconomic variables and changes in land-use intensity need to be included in global and regional models of wildfire, particularly in areas where fuel volume and continuity limit fire (Hessl 2011) and where human land uses reduce fuel. Predicted increases in fire occurrence due to rising temperatures and increasing aridity may be buffered by the effects of land-use intensification and its uneven distribution when long-running, highly regulated land-use 
policies are dismantled. As grazing becomes more concentrated, regions with long histories of frequent fire activity may experience fire exclusion, whereas other less impacted areas maintain some fire activity. Separating the interacting drivers of wildfire is crucial to understanding how climate change and human systems may interact to affect fire activity, forest resilience, and feedbacks to the atmosphere in future decades.

\section{ConClusion}

Recent land-use intensification has resulted in fire exclusion in the Siberian larch-dominated forests surrounding the capital city of Ulaanbaatar. Cluster analysis disentangled the complex interactions between land use and fire occurrence under changing climatic conditions. Our results indicate that land-use pressures are capable of overriding rapid changes in climate, particularly following the transition from highly regulated land-use policies to minimal regulation via privatization. The methods and findings described here can be applied to other semi-arid ecosystems where reduced regulation and increasing land-use pressures have the potential to reduce the risk of wildfires. Equally relevant is the trend toward urbanization, reduced pastoral activities, and increased fire activity observed in other regions of the world (Pausus 2004). Future research will need to address the critical role of land-use policy in affecting fire regimes both globally and locally. Global models of wildfire potential should include social, economic, and policy factors, which could have a significant impact on fire occurrence, particularly where fuel volume and continuity limit fire frequency and extent.

\section{ACKNOWLEDGMENTS}

This manuscript was completed with the help of numerous individuals. Cari Leland, Byambagerel Suran, Uyanga Ariya, and Soronzonbold Bayrbaatar assisted in the field. Elizabeth Flynn provided assistance in the laboratory, and Peter Brown provided comments on an earlier draft. Financial support was provided by the National Science Foundation (award \# 0816700) and the Explorers Club Washington Group.

\section{REFERENCES}

Arkhipov V, Moukanov BM, Khaidarov K, Goldammer JG. 2000. Overview on Forest Fires in Kazakhstan. Int For Fire News 22:40-8.
Arno SF, Sneck KM. 1977. A method for determining fire history in coniferous forests of the mountain west. USDA Forest Service GTR. INT-42. Intermountain Forest and Range Experiment Station, Ogden, UT.

Baisan CH, Swetnam TW. 1990. Fire history on a desert mountain range: Rincon Mountain Wilderness, Arizona, USA. Can J For Res 20:1559-69.

Batima P, Natsagdorj L, Gombluudev P, Erdenetsetseg P. 2005. Observed climate change in Mongolia. Assessments and Adaptations to Climate Change (AIACC). Working Paper No. 12. www.aiaccproject.org.

Brown JK. 1974. Handbook for Inventorying Downed Woody Material. USDA Forest Service GTR. INT-16. Ogden, UT: Intermountain Forest and Range Experiment Station.

Brown PM, Heyerdahl EK, Kitchen ST, Weber MH. 2008. Climate effects on historical fires (1630-1900) in Utah. Int J Wildland Fire 17:28-39.

Chapin FS, Randerson JT, McGuire AD, Foley JA, Field CB. 2008a. Changing feedbacks in the climate-biosphere system. Front Ecol Environ 6:313-20.

Chapin FS, Trainor SF, Huntington O, Lovecraft AL, Zavaleta E, Natcher DC, McGuire AD, Nelson JL, Ray L, Calef M, Fresco N, Huntington H, Rupp TS, DeWilde L, Naylor RL. 2008b. Increasing wildfire in Alaska's boreal forest: pathways to potential solutions of a wicked problem. BioScience 58:531-40.

Cook ER, D'Arrigo R, Mann M. 2002. A well-verified, multiproxy reconstruction of the winter North Atlantic Oscillation index since AD 1400. J Clim 15:1754-64.

D'Arrigo RD, Jacoby GC, Pederson N, Frank D, Buckley B, Nachin B, Mijiddorj R, Dugarjav C. 2000. Mongolian treerings, temperature sensitivity and reconstructions of Northern Hemisphere temperature. Holocene 10:669-72.

Dai A, Trenberth E, Qian T. 2004. A global dataset of Palmer Drought Severity Index for 1870-2002: relationship with soil moisture and effects of surface warming. Am Meteorol Soc 5:1117-30.

Dale VH, Joyce LA, McNulty S, Neilson RP. 2000. The interplay between climate change, forests, and disturbances. Sci Total Environ 262:201-4.

D'Arrigo RD, Jacoby GC, Frank D, Pederson N, Cook ER, Buckley B, Nachin B, Mijiddorj R, Dugarjav C. 2001. 1738 years of Mongolian temperature variability inferred from a tree-ring width chronology of Siberian pine. Geophys Res Lett 28:543-6.

D'Arrigo RD, Jacoby GC, Wilson R, Panagiotopoulos F. 2005. A reconstructed Siberian High index since A.D. 1599 from Eurasian and North American tree rings. Geophys Res Lett 32:L05705. doi:10.1029/2004GL022271.

Davagdorj D, Mijidorg R. 1996. Climate change issues in Mongolia. In: D. Davagdorj and L. Natsagdorj, Eds. Hydrometeorological issues in mongolia. Papers in hydrometeorology. Ulaanbaatar: Mongolian Institute of Meteorology and Hydrology. 230 pp, pp. 79-88.

Davi N, Pederson N, Leland C, Nachin B, Suran B, Jacoby G. 2013. Is eastern Mongolia drying? A long-term perspective of a multi-decadal trend. Water Resour Res. doi:10.1029/ 2012WR011834.

Donnegan JA, Veblen TT, Sibold JS. 2001. Climatic and human influences on fire history in Pike National Forest, Central Colorado. Can J For Res 31:1526-39.

Emerton L, Erdenesaikhan N, De Veen B, Tsogoo D, Janchivdorj L, Suvd P, Enkhtsetseg B, Gandolgor G, Dorisuren C, 
Sainbayar D, Enkhbaatar A. 2009. The Economic Value of the Upper Tuul Ecosystem. Mongolia Discussion Papers. East Asia and Pacific Sustainable Development Department. Washington, D.C.: World Bank.

Ermakov N, Cherosov M, Gogoleva P. 2002. Classification of ultracontinental boreal forests in central Yakutia. Folia Geobot 37:419-40.

Fernández-Giménez ME. 1999. Sustaining the steppes: a geographical history of pastoral land use in Mongolia. Geogr Rev 89:315-42.

Fernández-Giménez ME. 2006. Land use and land tenure in Mongolia: a brief history and current issues. In: Bedunah, DJ, McArthur ED, Fernández-Giménez ME, Eds. Rangelands of Central Asia: proceedings of the conference on transformations, issues, and future challenges, Proceeding RMRS-P-39, 2004 January 27, Salt Lake City, UT. Fort Collins, CO: U.S. Department of Agriculture, Forest Service, Rocky Mountain Research Station.

Field CB, Lobell DB, Peters HA, Chiariello NR. 2007. Feedbacks of terrestrial ecosystems to climate change. Annu Rev Environ Resour 32:1-29.

Flannigan M, Bergeron Y, Engelmark O, Wotton B. 1998. Future wildfire in circumboreal forests in relation to global warming. J Veg Sci 9:469-76.

Food and Agriculture Organization (FAO) of the United Nations. 2010. Mongolian dzud appeal 2010. http://www.fao.org/ emergencies/tce-appfund/tce-appeals/appeals/emergency-detail0/en/item/42611/icode/?uidf=17866, accessed May 2011 .

Fried JS, Gilles JK, Riley WJ, Moody TJ, de Blas CS, Hayhoe K, Moritz M, Stephens S, Torn M. 2008. Predicting the effect of climate change on wildfire behavior and initial attack success. Clim Change 87:251-64.

Girardin MP, Mudelsee M. 2008. Past and future changes in Canadian boreal wildfire activity. Ecol Appl 18:391-406.

Goldammer JC. 2002. Fire situation in Mongolia. Int For Fire News 26:75-83.

Goldammer JC, Davidenko EP, Kondrashov LG, Ezhov NI. 2004. Recent trends of forest fires in Central Asia and opportunities for regional cooperation in forest fire management. Regional Forest Congress Forest Policy: Problems and Solutions 25-27 November 2004, Bishkek, Kyrgyzstan.

Grissino-Mayer HD. 2001. FHX2-software for analyzing temporal and spatial patterns in fire regimes from tree rings. TreeRing Res 57:115-24.

Grissino-Mayer HD, Swetnam TW. 2000. Century scale climate forcing of fire regimes in the American Southwest. Holocene 10:213-20.

Grissino-Mayer HD, Baisan CH, Swetnam TW. 1995. Fire history in the Pinaleño Mountains of southern Arizona: effects of human-related disturbances. In: DeBano LF, Gottfried GJ, Hamre RH, Edminster CB, Folliott PF, Ortega-Rubio A, Eds. Biodiversity and management of the Madrean archipelago: the Sky Islands of southwestern United States and northwestern Mexico. USDA Forest Service General Technical Report RM-GTR-264. p. 399-407.

Grissino-Mayer HD, Romme WH, Floyd L, Hanna D. 2004. Climate and human influences on fire regimes of the southern San Juan Mountains, Colorado, USA. Ecology 85:1708-24.

Guyette RP, Muzika RM, Dey DC. 2002. Dynamics of an anthropogenic fire regime. Ecosystems 5:472-86.
Hellberg E, Hornberg G, Ostlund L. 2003. Vegetation dynamics and disturbance history in three deciduous forests in boreal Sweden. J Veg Sci 14:267-76.

Hessl AE. 2011. Pathways for climate change effects on fire: Models, data, and uncertainties. Prog Phys Geogr 35:393-407.

Hessl AE, McKenzie D, Schellhaas R. 2004. Drought and Pacific decadal oscillation linked to fire occurrence in the inland Pacific Northwest. Ecol Appl 14:425-42.

Hessl AE, Ariya U, Brown P, Byambasuren O, Green T, Jacoby G, Sutherland EK, Nachin B, Maxwell RS, Pederson N, De Grandpré L, Saladyga T, Tardif JC. 2012. Reconstructing fire history in central Mongolia from tree-rings. Int $\mathrm{J}$ Wildland Fire 21:86-92.

Honig KA, Fulé PZ. 2012. Simulating effects of climate change and ecological restoration on fire behaviour in a south-western USA ponderosa pine forest. Int J Wildland Fire 21:73142 .

IPCC (Intergovernmental Panel on Climate Change). 2007. Climate Change 2007-The Physical Science Basis. Working Group I Contribution to the Fourth Assessment Report of the IPCC. Cambridge: Cambridge University Press.

Jacoby GC, D'Arrigo RD, Davaajamts T. 1996. Mongolian tree rings and 20th century warming. Science 273:771-3.

Jacoby GC, D'Arrigo RD, Buckley B, Pederson N. 2009. Manshiir Hiid, ITRDB MONG002. World Data Center for Paleoclimatology Data. NOAA/NCDC Paleoclimatology Program, Boulder, CO.

Johnson DA, Sheehy DP, Miller D, Damiran D. 2006. Mongolian rangelands in transition. Secheresse 17(1/2):133.

Kasischke ES, Verbyla DL, Rupp TS, McGuire AD, Murphy KA, Jandt R, Barnes JL, Hoy EE, Duffy PA, Calef M, Turetsky MR. 2010. Alaska's changing fire regime-implications for the vulnerability of its boreal forests. Can J For Res 40:1313-24.

Keeley JE, Lubin D. 2003. Fire and grazing impacts on plant diversity and alien plant invasions in the southern Sierra Nevada. Ecol Appl 13:1355-74.

Kilpeläinen A, Kellomäki S, Strandman H, Venäläinen A. 2010. Climate change impacts on forest fire potential in boreal conditions in Finland. Clim Change 103:383-98.

Kitzberger T, Veblen TT. 1997. Influences of humans and ENSO on fire history of Austrocedrus Chilensis woodlands in Northern Patagonia, Argentina. Ecoscience 4:508-20.

Li J, Cook ER, D’Arrigo RD, Chen F, Gou X. 2008. Moisture variability across China and Mongolia: 1951-2005. Clim Dyn 32:1-14.

Liu Y, Stanturf J, Goodrick S. 2010. Trends in global wildfire potential in a changing climate. For Ecol Manag 259:685-97.

Mast JN, Veblen T, Linhart YB. 1998. Disturbance and climatic influences on a structure of ponderosa pine at the pine/ grassland ecotone, Colorado Front Range. J Biogeogr 25:74355.

McKenzie D, Gedalof Z, Peterson DL, Mote P. 2004. Climate change, wildfire, and conservation. Conserv Biol 18:890-902.

Meko DM. 1997. Dendroclimatic reconstruction with time varying predictor subsets of tree indices. J Clim 10:687-96.

Ministry of Nature and Environment, Mongolia. 2009. National Forest Cover maps.

Nyamjav B, Goldammer JG, Uibrig H. 2007. The forest fire situation in Mongolia. Int For Fire News 36:46-66. 
Overpeck JT, Rind D, Goldberg R. 1990. Climate induced changes in forest disturbance and vegetation. Nature 343:513.

Passovoy DM, Fule PZ. 2006. Snag and woody debris dynamics following sever wildfires in northern Arizona ponderosa pine forests. For Ecol Manag 223:237-46.

Pausas JG. 2004. Changes in fire and climate in the eastern Iberian Peninsula (Mediterranean basin). Clim Change 63:337-50.

Pederson N, Leland C, Nachin B, Hessl AE, Bell AR, MartinBenito D, Saladyga T, Suran B, Brown PM, Davi NM. 2013. Three centuries of shifting hydroclimatic regimes across the Mongolian breadbasket. Agric For Meteorol. Accessed February 11, 2013. doi:10.1016/j.agrformet.2012.07.003.

Rozas V. 2003. Regeneration patterns, dendroecology, and forest-use history in an old-growth beech-oak lowland forest in Northern Spain. For Ecol Manag 182:175-94.

Running SW. 2006. Is global warming causing more, larger wildfires? Science 13:927-8.

Saladyga T. 2011. Land use and climate impacts on fire regimes and forest regeneration in the Upper Tuul River Watershed, Mongolia. Doctoral Dissertation, West Virginia University, Morgantown, WV.

Samel AN, Wang WC, Liang XZ. 1999. The monsoon rainband over China and relationships with the Eurasian circulation. J Clim 12:115-31.

Sankey TT, Montagne C, Graumlich LJ, Lawrence R, Nielsen J. 2006. Lower forest-grassland ecotones and 20th century livestock herbivory effects in northern Mongolia. For Ecol Manag 233:36-44.

Savage M, Swetnam TW. 1990. Early 19th-century fire decline following sheep pasturing in a Navajo ponderosa pine forest. Ecology 71:2374-8.

Sivakumar MVK, Das HP, Brunini O. 2005. Impacts of present and future climate variability and change on agriculture and forestry in the arid and semi-arid tropics. Clim Change 70:3172.

Sneath D. 1998. State policy and pasture degradation in inner Asia. Science 281:1147-8.

Spracklen DV, Mickley LJ, Logan JA, Hudman RC, Yevich R, Flannnigan MD, Westerling AL. 2009. Impacts of climate change from 2000 to 2050 on wildfire activity and carbonaceous aerosol concentrations in the western United States. J Geophys Res 114:1-17.

Stocks BJ, Fosberg MA, Lynham TJ, Mearns L, Wotton BM, Yang Q, Jin J-Z, Lawrence K, Hartley GR, Mason JA, McKenney DW. 1998. Climate change and forest fire potential in Russian and Canadian boreal forests. Clim Change 38:1-13.

Stokes MA, Smiley TL. 1968. An introduction to tree-ring dating. Chicago: University of Chicago Press. 73 pp.

Swetnam TW, Betancourt JL. 1998. Mesoscale disturbance and ecological response to decadal climatic variability in the American Southwest. J Clim 11:3128-47.

Taylor AH, Beaty RM. 2005. Climatic influences on fire regimes in the northern Sierra Nevada Mountains, Lake Tahoe Basin, Nevada, USA. J Biogeogr 32:425-38.

Trouet V, Taylor AH, Wahl ER, Skinner CN, Stephens SL. 2010. Fire-climate interactions in the American West Since 1400 CE. Geophys Res Lett 37:L04702.

Ummenhofer CC, D'Arrigo RD, Anchukaitis KJ, Buckley BM, Cook ER. 2013. Links between Indo-Pacific climate variability and drought in the Monsoon Asia Drought Atlas. Clim Dyn 40:1319-34.

United Nations Economic and Social Council. 2002. Poverty statistics in Mongolia. Economic and Social Commission for Asia and the Pacific, Committee on Statistics. Thirteenth Session, 27-29 November 2002. Bangkok, Thailand.

Valendik EN, Ivanova GA, Chuluunbator ZO, Goldammer JG. 1998. Fire in forest ecosystems of Mongolia. Int For Fire News 19:58-63.

Veblen T, Kitzberger T, Villalba R, Donnegan J. 1999. Fire history in northern Patagonia: the roles of humans and climatic variation. Ecol Monogr 69:47-67.

Westerling AL, Hidalgo HG, Cayan DR, Swetnam TW. 2006. Warming and earlier spring increase western U.S. forest wildfire activity. Science 313:940-3.

Wotton BM, Flannigan MD. 1993. Length of fire season in a changing climate. For Chronicle 69:187-92.

Yang G, Di X, Guo Q, Shu Z, Zeng T, Yu H, Wang C. 2011. The impact of climate change on forest fire danger rating in China's boreal forest. J For Res 22:249-57. 